\title{
PENGEMBANGAN MODUL KARYA REKAYASA ELEKTRONIKA PRAKTIS BERBASIS APLIKASI LIVEWIRE
}

\author{
A. Fibra Cahyani ${ }^{1}$, K. Udy Ariawan ${ }^{2}$, I G. Ratnaya ${ }^{3}$ \\ ${ }_{1,3}$ Prodi Pendidikan Teknik Elektro, Universitas Pendidikan Ganesha, Singaraja \\ 2Prodi Teknik Elektronika, Universitas Pendidikan Ganesha, Singaraja \\ e-mail: fibracahyani971@gmail.com, udyariawan@gmail.com, gede.ratnaya@undiksha.ac.id
}

\begin{abstract}
Abstrak
Penelitian pengembangan ini bertujuan untuk mengembangkan modul karya rekayasa elektronika praktis berbasis aplikasi livewire bagi siswa kelas XII di SMA Negeri 4 Singaraja pada mata pelajaran Prakarya dan Kewirausahaan. Penelitian ini merupakan jenis penelitian $R \& D$ dengan mengadaptasi langkah pengembangan dari model pengembangan Sugiyono. Modul pembelajaran yang dikembangkan di validasi oleh ahli media dan ahli materi serta guru bidang studi. Perhitungan instrument untuk para ahli dan uji coba siswa menggunakan skala Likert. Sampel penelitian dalam uji coba lapangan terbatas adalah 37 orang siswa kelas XII MIPA 4 SMA Negeri 4 Singaraja. Hasil penelitian modul pembelajaran dari ahli media memperoleh persentase tingkat kelayakan sebesar 92,67\% dengan kualifikasi sangat baik, ahli materi memperoleh persentase tingkat kelayakan $90 \%$ dengan kualifikasi sangat baik, serta guru bidang studi memperoleh persentase tingkat kelayakan sebesar $88 \%$ dengan kualifikasi sangat baik. Tahap uji coba produk memperoleh hasil tingkat pencapaian kelayakan pada uji coba kelompok kecil sebesar $89,97 \%$ dan uji coba lapangan sebesar $91,42 \%$. Kedua persentase tersebut termasuk kualifikasi sangat baik. Sehingga modul pembelajaran yang dikembangkan layak untuk diterapkan pada mata pelajaran Prakarya dan Kewirausahaan.
\end{abstract}

Kata kunci: Livewire, Modul Karya Rekayasa, Prakarya dan Kewirausahaan

\begin{abstract}
This development research aims to develop the module of practical electronics engineering based on livewire application for student grade XII in Senior High School 4 Singaraja in the subject field of workshops and entrepreneurship. This research is a kind of R\&D research which is adapted the development steps from development sample proposed by Sugiyono. The developed module has been validated by the experts and teacher in the subject field. In this research, Likert scale is used to the instrument calculation for the experts and student trials. The research sample in the experiment is limited with only 37 students from grade XII MIPA 4 Senior High School 4 Singaraja. The research found that the module got $92,67 \%$ of eligibility percentage level from the media experts with excellent qualification, $90 \%$ of eligibility percentage level from the material experts with excellent qualification and $88 \%$ of eligibility percentage level from the subject teachers with excellent qualification. The product trial steps got $89,97 \%$ of eligibility percentage level from the small group trial and $91,42 \%$ from the field trials, both percentages are classified as excellent qualification. Therefore, the developed modules are eligible to apply in the subject field of workshops and entrepreneurship.
\end{abstract}

Keywords: Livewire, module of engineering work, workshops and entrepreneurship

\section{Pendahuluan}

Pendidikan di sekolah dilakukan dalam suatu proses yang disebut pembelajaran. Belajar menunjukkan suatu aktivitas menuju perubahan tingkah laku pada diri sendiri individu melalui proses interaksi dengan lingkungannya. Sedangkan pembelajaran menurut Sutikno (2008:37) merupakan suatu sistem lingkungan belajar yang terdiri dari tujuan pembelajaran, materi pelajaran, kegiatan belajar mengajar, metode, media, sumber belajar dan evaluasi. Usaha untuk mencapai tujuan proses belajar mengajar dipengaruhi oleh beberapa faktor, salah satu faktor itu adalah pengajar atau pendidik (guru). Tugas seorang pendidik adalah membantu, membimbing dan memfasilitasi peserta didik untuk mencapai tujuannya. 
Demi meningkatkan hasil belajar peserta didiknya, guru yang ideal senantiasa berupaya dengan berbagai strategi, termasuk diantaranya ialah dengan menggunakan media belajar yang efektif dan menyenangkan bagi siswa. Media belajar merupakan sarana bagi guru untuk memudahkan penyampaian ilmu pengetahuan kepada peserta didiknya serta mempermudah pencapaian hasil belajar yang diinginkan. Menurut Arsyad (2007:15) pemanfaatan media dalam pembelajaran dapat membangkitkan keinginan dan minat baru, meningkatkan motivasi dan rangsangan kegiatan belajar, dan bahkan berpengaruh secara psikologis bagi peserta didik.

Untuk itu upaya pembelajaran yang bisa dilakukan pendidik adalah pada pengembangan media pembelajaran. Pengembangan media pembelajaran yang dilakukan pendidik harus berusaha agar materi pembelajaran yang disampaikan mampu diserap dan dimengerti dengan mudah oleh peserta didik. Gerlach \& Ely dalam (Arsyad, 2006) mengatakan bahwa media apabila dipahami secara garis besar adalah manusia, materi, atau kejadian yang membangun kondisi yang membuat siswa mampu memperoleh pengetahuan, keterampilan, atau sikap. Dalam pengertian ini, guru, buku teks, dan lingkungan sekolah merupakan media. Menurut AECT (Association of Education and Communication Technology) dalam (Arsyad, 2006), media sebagai segala bentuk dan saluran yang digunakan untuk menyampaikan pesan atau informasi. Sejalan dengan itu, Hamidjojo dalam (Arsyad, 2006) memberi pengertian media sebagai semua bentuk perantara yang digunakan oleh manusia untuk menyampaikan atau menyebar ide, gagasan, atau pendapat sehingga ide, gagasan atau pendapat yang dikemukakan itu sampai kepada penerima yang dituju.

Perkembangan informasi dan teknologi, merupakan salah satu pendukung untuk mengembangkan inovasi pembelajaran khususnya pada media pembelajaran. Akan tetapi perkembangan informasi dan teknologi tersebut belum dioptimalkan untuk meningkatkan kualitas pendidikan. Pemanfaatan informasi dan teknologi tersebut dapat diupayakan untuk membuat suatu media pembelajaran yang dapat membuat peserta didik secara aktif melakukan proses pembelajaran, dimana peran peserta didik tidak hanya sebagai penerima, tetapi juga secara aktif mendapatkan pengalaman belajar bermakna.

Dari pemaparan beberapa ahli tersebut dapat disimpulkan bahwa media pembelajaran adalah komponen sumber belajar yang mengandung materi instruksional di lingkungan siswa yang paling penting dalam mendukung dan merangsang siswa melaksanakan proses belajar. Salah satu media pembelajaran yang dapat digunakan untuk merangsang siswa dalam belajaran ialah bahan ajar berupa modul. Bahan ajar adalah segala bentuk bahan yang digunakan untuk membantu guru atau instruktur dalam melaksanakan kegiatan belajar mengajar di kelas. Bahan ajar memiliki posisi amat penting dalam pembelajaran, yakni sebagai representasi (wakil) dari penjelasan guru di depan kelas. Agar bahan ajar yang diberikan mampu diserap dengan baik oleh siswa, maka seorang guru diharuskan memerlukan sebuah modul ajar. (Santyasa, 2009), mengemukakan bahwa modul ajar adalah suatu cara pengorganisasian materi pelajaran yang memperhatikan fungsi pendidikan.

Menurut (Santyasa, 2009) keuntungan yang diperoleh dari pembelajaran dengan penerapan modul adalah sebagai berikut: 1) meningkatkan motivasi peserta didik, karena setiap kali mengerjakan tugas pelajaran yang dibatasi dengan jelas dan sesuai dengan kemampuan; 2) setelah dilakukan evaluasi, pendidik dan peserta didik mengetahui benar, pada modul yang mana peserta didik telah berhasil dan pada bagian modul yang mana mereka belum berhasil; 3) peserta didik mencapai hasil sesuai dengan kemampuannya; 4) bahan pelajaran terbagi lebih merata.

Bahan ajar atau modul sangat penting digunakan dalam menunjang pelajaran salah satunya pada mata pelajaran Prakarya dan Kewirausahaan. Mata pelajaran Prakarya dan Kewirausahaan merupakan mata pelajaran baru yang ada sejak diterapkannya Kurikulum 2013. Mata pelajaran Prakarya dan Kewirausahaan dapat digolongkan ke dalam pengetahuan transcience-knowledge, yaitu mengembangkan pengetahuan dan melatih keterampilan kecakapan hidup berbasis seni, teknologi, dan ekonomi. Pembelajaran ini berawal dengan melatih kemampuan ekspresi kreatif untuk menuangkan ide dan gagasan agar 
menyenangkan orang lain, dan dirasionalisasikan secara teknologis sehingga keterampilan tersebut bermuara apresiasi teknologi terbarukan, hasil ergonomis dan aplikatif dalam memanfaatkan lingkungan sekitar dengan memperhatikan dampaknya terhadap ekosistem, manajemen, dan ekonomis.

Peserta didik mendapatkan mata pelajaran Prakarya dan Kewirausahaan dimaksudkan agar dapat bersaing dengan lulusan SMK dalam hal menciptakan lapangan pekerjaan baru dan juga memiliki keterampilan dalam menggunakan berbagai perkakas serta aplikasi yang ada. Dalam pasal 35 Ayat (1) Undang-Undang Nomor 20 Tahun 2003 tentang Sistem Pendidikan Nasional, kompetensi lulusan yang mencakup sikap, pengetahuan, dan keterampilan, yang akan menjadi acuan bagi pengembangan kurikulum dalam rangka mewujudkan tujuan pendidikan nasional. Maka dari itu, dengan adanya mata pelajaran ini disamping peserta didik mempunyai pengetahuan dengan jurusannya masing-masing, peserta didik juga mempunyai pengetahuan mengenai soft skill/keterampilan.

Pada kelas XII SMA Negeri 4 Singaraja diterapkan bidang rekayasa dengan bahasan pokok yaitu sumber daya karya rekayasa elektronika praktis. Pada materi sumber daya karya rekayasa elektronika praktis ini, peserta didik mempelajari tentang memahami sumber daya yang dibutuhkan dalam mendukung proses produksi usaha rekayasa praktis, dan mendesain proses produksi karya rekayasa elektronika praktis berdasarkan identifikasi kebutuhan sumber daya, teknologi, dan prosedur berkarya dengan pendekatan budaya setempat dan lainnya. Peserta didik juga harus memiliki kreatifitas yang cukup dan rasa ingin tahu yang tinggi, untuk bisa lebih cepat memahami materi sehingga akan memberikan bekal keterampilan untuk peserta didik kedepannya.

Berdasarkan hasil pengamatan dan observasi pada mata pelajaran Prakarya dan Kewirausahaan bidang rekayasa di SMA Negeri 4 Singaraja belum tersedianya media pembelajaran yang dapat mendukung proses pembelajaran, sehingga peserta didik mengalami kesulitan menerima materi pembelajaran. Kurang maksimalnya dalam memanfaatkan sarana dan prasarana yang ada dalam menciptakan dan mengembangkan media pembelajaran yang efektif dan efisien untuk siswa, serta kurang efektifnya penyampaian materi pelajaran dalam proses pembelajaran sehingga membuat minat siswa untuk belajar tidak maksimal.

Selain itu, permasalahan yang peneliti temui saat melakukan pengamatan dan observasi yaitu siswa cenderung tergantung akan bantuan guru. Hal itu dikarenakan tidak tersedianya media pembelajaran seperti modul pembelajaran sebagai sumber belajar mandiri siswa. Selain itu guru lebih kepada menguasai kelas dalam pembelajaran, dalam hal ini guru yang lebih mendominasi pembelajaran sedangkan siswa hanya mampu terfokus pada apa yang dibicarakan guru, ini yang menyebabkan siswa menjadi enggan untuk berpendapat serta mencoba kemampuan dirinya, sehingga potensi diri yang siswa miliki tidak dapat berkembang secara optimal. Maka dari itu sebagai seorang pendidik perlu melakakukan suatu pembaharuan atau inovasi pembelajaran agar proses pembelajaran yang berlangsung tidak monoton, melainkan pembelajaran akan lebih menarik serta siswa pun terpacu untuk serius dalam belajar. Salah satu caranya adalah dengan memanfaatkan kecanggihan teknologi informasi dengan membuat media pembelajaran yang berupa modul.

Anwar dalam (Irfan, 2014) berpendapat bahwa modul pembelajaran adalah bahan ajar yang disusun secara sistematis dan menarik yang mencakup isi materi, metode dan evaluasi yang dapat digunakan secara mandiri untuk mencapai kompetensi yang diharapkan. Sejalan dengan Suryosubroto (1983) modul adalah satu unit program belajar mengajar terkecil yang secara terperinci menggariskan: (1) tujuan pembelajaran yang akan dicapai (2) topik yang akan dijadikan pangkal proses belajar mengajar (3) pokok-pokok materi yang akan dipelajari (4) kedudukan dan fungsi modul dalam kesatuan program yang lebih luas (5) peranan guru dalam proses pembelajaran (6) alat-alat dan sumber yang akan dipergunakan (7) kegiatankegiatan belajar yang harus dilakukan dan dihayati murid secara berurutan (8) lembaran kerja yang harus diisi oleh anak (9) program evaluasi yang akan dilaksanakan.

Modul sebagai sumber belajar juga mempunyai sifat-sifat khas yang menjadikannya berbeda dengan model sumber belajar yang lain. Sifat-sifat tersebut adalah: (1) merupakan 
unit atau paket pembelajaran terkecil (2) memuat rangkaian kegiatan belajar yang direncanakan dan sistematis (3) memuat tujuan belajar (KI dan KD) yang dirumuskan secara eksplesit dan spesifik (4) memungkinkan bagi siswa belajar secara mandiri (independent) (5) merupakan realisasi pengakuan perbedaan individual. Modul pembelajaran merupakan salah satu bahan belajar yang dapat dimanfaatkan oleh siswa secara mandiri. Modul yang baik harus disusun secara sistematis, menarik dan jelas. Sebuah modul bermakna, jika peserta didik dapat dengan mudah menggunakannya

Dari pemaparan diatas untuk memenuhi kompetensi dasar pendidik harus memiliki kemampuan di dalam melakukan suau inovasi pembelajaran, maka seorang guru penting dan harus mampu membuat sarana pembelajaran yang menarik yaknimedia pembelajaran yang dapat mendukung proses pembelajaran. Dengan demikian pada mata pelajaran Prakarya dan Kewirausahaan akan menjadi materi pembelajaran yang menarik dan mudah dipahami, jika disajikan dengan suatu media yang praktis dan fleksibel, sehingga peserta didik dapat melakukan proses belajar dengan baik dan benar sesuai dengan kompetensi dasar yang harus dicapai yaitu mampu mendesain proses produksi karya rekayasa elektronika praktis berdasarkan identifikasi kebutuhan sumber daya, teknologi dan prosedur berkarya dengan pendekatan budaya setempat dan lainnya.

Berdasarkan latar belakang masalah dan landasan teori diatas, terkait dengan pentingnya penggunaan media pembelajaran dalam proses pembelajaran pada mata pelajaran Prakarya dan Kewirausahaan maka perlu dilakukan suatu penelitian yang berjudul pengembangan modul karya rekayasa elektronika praktis berbasis aplikasi livewire bagi siswa kelas XII di SMA Negeri 4 Singaraja.

\section{Metode}

Metode penelitian yang digunakan dalam penelitian ini menggunakan pendekatan penelitian pengembangan (Research and Development). Metode penelitian dan pengembangan adalah metode penelitian yang digunakan untuk menghasilkan produk tertentu, dan menguji keefektifan produk tersebut. Untuk dapat menghasilkan produk tertentu digunakan penelitian yang bersifat analisa kebutuhan (Sugiyono, 2015:407). Penelitian pengembangan ini mengacu pada model dari Sugiyono (2015:409) yang telah dimodifikasi pada tahapannya. Adapun langkah-langkah penggunaan metode Research and Development (R\&D) dapat dilihat pada Gambar 1.

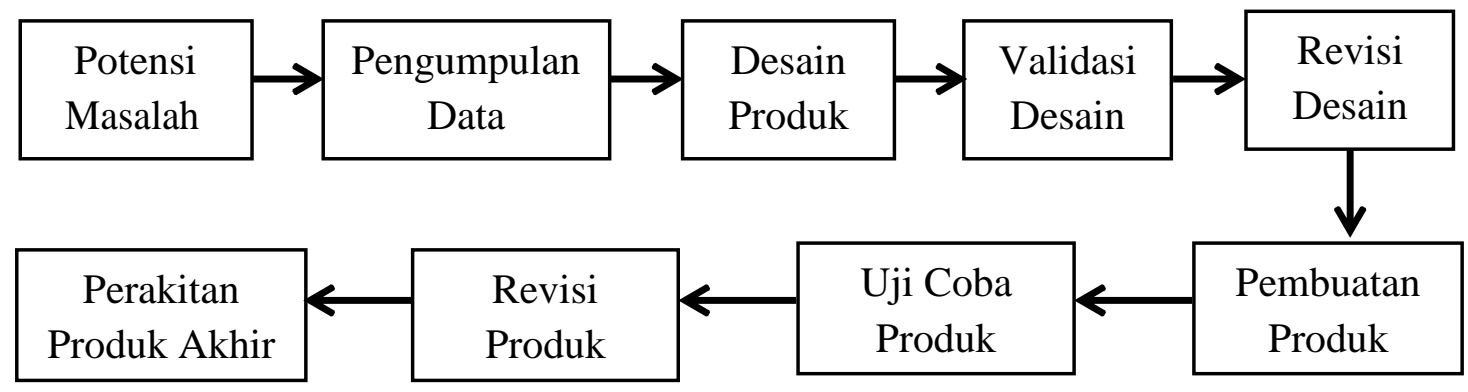

Gambar 1. Langkah-langkah penggunaan Metode Research and Development (R\&D) (Adaptasi dari Sugiyono, 2015:409)

Berdasarkan Gambar 1, terkait langkah-langkah penggunaan metode R\&D adalah: (1) Potensi Masalah. Menurut Sugiyono (2015:409), penelitian dapat berangkat dari adanya potensi atau masalah. Permasalahan dalam penelitian ini adalah kurang tersedianya media pembelajaran pada mata pelajaran prakarya dan kewirausahaan sehingga membuat siswa kurang termotivasi dalam mengikuti pembelajaran dikelas. (2) Pengumpulan Data, Pada penelitian ini, peneliti mengumpulkan data dengan metode angket atau kuesioner. Setiap item dari kuesioner tersebut merupakan pernyataan positif yang memilliki 5 pilihan jawaban dengan skor mulai dari 1 sampai 5. 
Angket tersebut nantinya akan digunakan untuk validasi ahli materi dan media, guru bidang studi, serta dari siswa. (3) Desain Produk, pada tahap ini penulisan modul diawali dengan menyusun buram atau draft/konsep modul. Modul yang dihasilkan dinyatakan sebagai buram sampai dengan selesainya proses validasi dan uji coba. Bila hasil uji coba telah dinyatakan layak, barulah suatu modul dapat diimplementasikan secara riil di lapangan. (4) Validasi Desain, validasi desain merupakan proses kegiatan untuk menilai apakah rancangan produk sudah rasional dan efektif. Dikatakan secara rasional, karena validasi di sini masih bersifat penilaian berdasarkan pemikiran rasional, belum fakta lapangan (Sugiyono, 2015:414).

Jadi hasil rancangan produk, Modul Karya Rekayasa Elektronika Praktis Berbasis Aplikasi Livewire kemudian divalidasi oleh dosen ahli bidang Pengembangan Modul. (5) Revisi Desain, Setelah desain produk Modul Karya Rekayasa Elektronika Praktis Berbasis Aplikasi Livewire divalidasi, kemudian mendiskusikan dengan dosen ahli bidang Pengembangan Modul. Maka akan dapat diketahui kelemahannya, kelemahan tersebut selanjutnya direvisi kembali dan dilanjutkan ketahap pembuatan produk. (6) Pembuatan Produk, Setelah desain produk diperbaiki maka tahap selanjutnya yaitu pembuatan produk modul karya rekayasa elektronika praktis berbasis aplikasi livewire.

Setelah modul karya rekayasa elektronika praktis berbasis aplikasi livewire selesai dibuat selanjutnya perlu dilakukan uji coba produk untuk mengetahui apakah produk tersebut layak atau tidak digunakan dalam penelitian. (7) Uji Coba Produk, Uji coba produk ini dilakukan pada siswa untuk mengetahui apakah modul tersebut selanjutnya layak digunakan dalam penelitian. Untuk mengetahui layak atau tidaknya modul tersebut maka perlu dilakukan penyebaran angket atau kuesioner yang berkaitan dengan modul karya rekayasa elektronika praktis berbasis aplikasi livewire.

Sebelum angket disebarkan, maka angket tersebut diuji cobakan terlebih dahulu dengan uji pakar dan uji keterbacaan. Uji pakar dilakukan untuk mengetahui apakah butir item pada kuesioner yang dibuat sudah sesuai dengan kisi-kisi yang dirancang baik dari segi aspek penilaian maupun indikatornya. Uji keterbacaan dilakukan setelah selesai melakukan uji pakar, uji keterbacaan dilakukan dengan menyebarkan kuesioner yang nantinya akan digunakan dalam penelitian. Tujuan dari uji keterbacaan adalah untuk memperoleh skor dari tiap butir kuesioner, yang nantinya skor tersebut dihitung dengan menggunakan rumus Product Moment untuk mengetahui butir-butir soal yang valid pada kuesioner.

Setelah dilakukan uji pakar dan uji keterbacaan, selanjutnya dilakukan juga uji validitas terhadap angket penelitian yang bertujuan untuk menguji valid atau tidaknya item atau butirbutir instrumen penelitian. Validitas item angket ini ditentukan melalui uji t yaitu jika $t_{\text {hitung }}>t_{\text {tabel }}$ dengan taraf Signifikan 5\% maka butir soal dinyatakan valid dan jika sebaliknya maka butir soal tidak signifikan atau tidak valid. (8) Revisi Produk, Pengujian efektivitas produk Modul Karya Rekayasa Elektronika Praktis Berbasis Aplikasi Livewire dapat dilihat dari tingkat kelayakan untuk pendukung proses pembelajaran dalam mata pelajaran Prakarya dan Kewirausahaan di bidang rekayasa. Jika tidak ada yang perlu direvisi maka produk Modul Karya Rekayasa Elektronika Praktis Berbasis Aplikasi Livewire untuk mata pelajaran Prakarya dan Kewirausahaan sudah dalam kualifikasi baik dan layak digunakan. (9) Perakitan Produk Akhir, Tahap terakhir yaitu perakitan produk. Pada tahap ini peneliti membuat 3 produk modul karya rekayasa elektronika praktis berbasis aplikasi livewire yang telah diuji cobakan terlebih dahulu dan direvisi, sehingga diharapkan dari hasil revisi tersebut didapatkan hasil yang terbaik.

Sugiyono (2015:199) menyatakan bahwa metode angket merupakan teknik pengumpulan data yang dilakukan dengan cara memberi seperangkat pertanyaan atau pernyataan tertulis kepada responden untuk dijawabnya. Dalam penelitian ini teknik analisa data menggunakan statistik deskriptif persentase dan jenis data yang digunakan adalah data kuantitatif. Menurut Sugiyono (2016:29) "Statistik deskriptif adalah statistik yang berfungsi untuk mendeskripsikan atau memberi gambaran terhadap obyek yang diteliti melalui data sampel atau populasi sebagaimana adanya, tanpa melakukan analisis dan membuat kesimpulan yang berlaku untuk umum". Penelitian data kuantitatif akan diperoleh berupa 
angka-angka yang akan diolah dengan menggunakan rumus-rumus statistik baik secara manual atau menggunakan komputer.

Instrumen yang digunakan pada penelitian ini adalah 1) lembar validasi media pembelajaran yang diisi oleh dosen ahli media untuk mengetahui sejauh mana kualitas media yang dihasilkan, sehingga media ini layak untuk di uji cobakan, 2) lembar validasi materi yang diisi oleh dosen dan guru untuk mengetahui sejauh mana kelengkapan materi yang disajikan, sehingga materi ini layak disampaikan pada siswa, 3) lembar angket respon siswa. Kemudian hasil validasi dianalisis dan diperoleh persentase kelayakan berdasarkan hasil bagi jumlah rata-rata skor yang diperoleh dengan jumlah rata-rata skor maksimal, sehingga dapat ditetapkan tabel distribusi range persentase dan kriteria kualifikasi seperti pada tabel 1.

Tabel 1. Kualifikasi Tingkat Kelayakan Berdasarkan Persentase

\begin{tabular}{ccc}
\hline No & Interval & Kriteria \\
\hline 1 & $84.01 \%-100 \%$ & Sangat Baik \\
2 & $68.00 \%-84.00 \%$ & Baik \\
3 & $52.01 \%-68.00 \%$ & Cukup \\
4 & $36.01 \%-52.00 \%$ & Kurang \\
5 & $20.00 \%-36.00 \%$ & Sangat Kurang \\
\hline
\end{tabular}

\section{Hasil dan Pembahasan}

Setelah dilakukan uji pakar dan uji keterbacaan pada kuesioner yang dijadikan instrument penelitian, diperoleh hasil bahwa ke 30 butir item kuesioner tersebut relevan dan valid, sehingga 30 butir item kuesioner tersebut layak digunakan dalam penelitian di lapangan dengan revisi. Adapun hal-hal yang di revisi dalam angket atau kuesioner oleh ahli pakar dan siswa adalah sebagai berikut: (1) pada angket uji media, terdapat kesalahan tata tulis pada butir soal nomor 16. (2) pada angket uji materi, terdapat tata bahasa yang belum sesuai KBBI pada butir soal nomo 8 serta kesalahan tata tulis pada butir soal nomor 23. (3) pada angket uji coba, terdapat pernyataan yang sama pada butir soal nomor 6 dan 9, dan pernyataan yang menggunakan bahasa yang rancu pada butir soal nomor 10 dan 11, serta kesalahan tata tulis pada butir soal nomor 13, 21, 25.

Produk akhir yang dihasilkan dalam pengembangan ini adalah modul karya rekayasa elektronika praktis berbasis aplikasi livewire sebagai media pembelajaran prakarya dan kewirausahaan bagi siswa kelas XII di SMA Negeri 4 Singaraja. Data uji coba produk pengembangan media pembelajaran ini dilakukan dalam tiga tahap. Tahap pertama diperoleh dari hasil penilaian terhadap produk pengembangan media pembelajaran yang dilakukan oleh ahli media. Tahap kedua diperoleh dari hasil penilaian ahli materi yang dilakukan oleh dosen dan guru bidang studi. Dan tahap ketiga diperoleh dari hasil penilaian siswa kelas XII MIPA 4 di SMA Negeri 4 Singaraja.

Ahli media yang bertindak sebagai validator adalah Gede Aditra Pradnyana, S.Kom., M.Kom yang merupakan dosen Pendidikan Teknik Informatika, sedangkan ahli materi yang bertindak sebagai validator adalah Irma Yuliandari, S.Pd., M.Pd selaku guru bidang studi dan I Wayan Sutaya, ST., MT selaku dosen Pendidikan Teknik Elektro. Instrumen yang digunakan untuk melakukan validasi media, vaidasi materi dan uji coba terdiri dari 30 pertanyaan. Ringkasan hasil uji validasi ahli media, guru bidang studi, dan ahli materi disajikan pada tabel 2, tabel 3, dan tabel 4. 
Tabel 2. Ringkasan Hasil Uji Ahli Media

\begin{tabular}{cccc}
\hline No & Aspek Penilaian & Skor Maksimal & Rata-rata Skor \\
\hline A & Ukuran Modul & 5 & 5 \\
B & Desain Sampul Modul (Cover) & 5 & 4,3 \\
C & Desain Isi Modul & 5 & 4,6 \\
\hline \multicolumn{2}{c}{ Jumlah } & 15 & 13,9 \\
\hline
\end{tabular}

Dari data pada tabel 2, didapakan jumlah rata-rata skor penilaian sebesar 13,9. Kemudian dihitung persentase tingkat pencapaian kualitas modul pembelajaran dengan rumus persentase kelayakan sehingga didapatkan hasil analisis dari ahli media sebesar $92,67 \%$ berada dikualifikasi sangat baik.

Tabel 3. Ringkasan Hasil Uji Guru Bidang Studi

\begin{tabular}{cccc}
\hline No & Aspek Penilaian & Skor Maksimal & Rata-rata Skor \\
\hline A & Kelayakan Isi & 5 & 4,5 \\
B & Kelayakan Penyajian & 5 & 4,4 \\
C & Bahasa & 5 & 4,25 \\
\hline \multicolumn{2}{r}{ Jumlah } & 15 & 13,2 \\
\hline
\end{tabular}

Tabel 3. menunjukkan ringkasan hasi uji validasi guru bidang studi, dari hasil tersebut diperoleh persentase tingkat pencapaian kualitas modul pembelajaran sebesar $88 \%$ berada dikualifikasi sangat baik.

Tabel 4. Ringkasan Hasil Uji Ahli Materi

\begin{tabular}{clcc}
\hline No & \multicolumn{1}{c}{ Aspek Penilaian } & Skor Maksimal & Rata-rata Skor \\
\hline A & Kelayakan Isi & 5 & 4,7 \\
B & Kelayakan Penyajian & 5 & 4,4 \\
C & Bahasa & 5 & 4,3 \\
\hline \multicolumn{2}{r}{ Jumlah } & 15 & 13,4 \\
\hline
\end{tabular}

Tabel 4. menunjukkan ringkasan hasi uji validasi ahli materi, dari hasil tersebut diperoleh persentase tingkat pencapaian kualitas modul pembelajaran sebesar $90 \%$ berada dikualifikasi sangat baik. Sedangkan uji coba produk dilakukan sebanyak dua kali yaitu uji coba kelompok kecil dengan subyek siswa kelas XII MIPA 6 sebanyak 9 orang dan uji coba lapangan dengan subyek uji coba seluruh siswa kelas XII MIPA 4 di SMA Negeri 4 Singaraja. Ringkasan hasil uji coba kelompok kecil dan uji coba lapangan dapat dilihat pada tabel 5 dan tabel 6 .

Tabel 5. Ringkasan Hasil Uji Coba Kelompok Kecil

\begin{tabular}{cccc}
\hline No & Aspek Penilaian & Skor Maksimal & Rata-rata Skor \\
\hline A & Aspek Penyajian Isi/Materi & 45 & 39,8 \\
B & Aspek Bahasa & 45 & 40 \\
C & Aspek Manfaat & 45 & 41,66 \\
\hline & Jumlah & 135 & 121,46 \\
\hline
\end{tabular}


Tabel 6. Ringkasan Hasil Uji Coba Lapangan

\begin{tabular}{cccc}
\hline No & Aspek Penilaian & Skor Maksimal & Rata-rata Skor \\
\hline A & Aspek Penyajian Isi/Materi & 185 & 170,8 \\
B & Aspek Bahasa & 185 & 164,8 \\
C & Aspek Manfaat & 185 & 169,8 \\
\hline & Jumlah & 555 & 121,46 \\
\hline
\end{tabular}

Dari hasil uji coba kelompok kecil yang disajikan pada tabel 5, didapatkan jumlah ratarata penilaian keseluruhan yang diperoleh sebesar 121,46, sehingga jika dihitung dengan rumus persentase diperoleh tingkat pencapaian kualitas modul pembelajaran sebesar $89,97 \%$ dengan kualifikasi sangat baik. Sedangkan pada tabel 6 , terkait uji coba lapangan didapatkan jumlah rata-rata penilaian keluruhan sebesar 505,31 dengan 37 responden, didapatkan persentase tingkat kelayakan sebesar $91,05 \%$ dengan kualifikasi sangat baik.

Berdasarkan hasil analisis dari penilaian dosen dan guru terhadap media pembelajaran ini, diperoleh hasil ahli media memberikan nilai 92,67\% (Sangat Layak), ahli materi dari guru bidang studi memberikan nilai $88 \%$ (Sangat Layak) dan ahli materi dari dosen memberikan nilai $90 \%$ (Sangat Layak), sedangkan hasil uji coba kelompok kecil memperoleh hasil sebesar $89,97 \%$ dan uji coba lapangan sebesar $91,05 \%$, maka dapat disimpulkan bahwa hipotesis didukung oleh data, artinya pengembangan modul karya rekayasa elektronika praktis berbasis aplikasi livewire bagi siswa kelas XII di SMA Negeri 4 Singaraja layak digunakan sebagai alat bantu pembelajaran pada materi pokok sumber daya karya rekayasa elektronika praktis.

Hal ini juga di perkuat berdasarkan hasil penelitian yang telah dilakukan sebelumnya diantaranya: (1) Syahrir dan Susilawati tahun 2015 yang berjudul "Pengembangan Modul Pembelajaran Matematika Siswa SMP" hasil penelitiannya menunjukkan bahwa modul yang dikembangkan memperoleh rata-rata $80,89 \%$ dengan kategori sangat layak. (2) penelitian yang dilakukan oleh Arif Muhafid dkk (2013) yang berjudul "Pengembangan Modul IPA Terpadu Berpendekatan Keterampilan Proses Pada Tema Bunyi di SMP Kelas VIII" dengan hasil penelitian menunjukkan bahwa modul yang dikembngkan memperoleh rata-rata hasil belajar siswa sebesar 90,40. (3) penelitian yang dilakukan oleh Nailin Asfiah, dkk (2013) yang berjudul "Pengembangan Modul IPA Terpadu Kontekstual Pada Tema Bunyi" dengan hasil penelitian yang menunjukkan bahwa modul yang dikembangkan sangat layak digunakan sebagai bahan ajar dengan ketuntasan klasikal mencapai 100\%. Dengan menggunakan metode $R \& D$.

Selain itu, dari hasil penyebaran angket tersebut dapat diketahui kelebihan serta kekurangan dari media pembelajaran. Adapun kelebihan dari modul tersebut adalah sebagai berikut: (1) Bahasa yang digunakan pada modul mudah dipahami, (2) Setiap penjelasan dilengkapi dengan gambar yang mendukung pemahaman siswa, (3) Setiap bab terdapat latihan soal untuk mengevaluasi pemahaman siswa. Serta kelemahan dari modul karya rekayasa elektronika praktis berbasis aplikasi livewire adalah sebagai berikut: (1) Penjelasan dengan gambar belum diberikan penanda, (2) Aspek penilaian belum mencantumkan kriteria untuk kegiatan belajar evaluasi.

\section{Simpulan dan Saran}

Berdasarkan analisis data dari pelaksanaan penelitian serta mengkaji hasil-hasil yang diperoleh, maka dapat disimpulkan bahwa pengembangan modul karya rekayasa elektronika praktis berbasis aplikasi livewire sebagai media pembelajaran prakarya dan kewirausahaan bagi siswa kelas XII di SMA Negeri 4 Singaraja mendapatkan kategori sangat baik dengan rerata persentase sebesar $91,05 \%$ sehingga layak digunakan dan diterapkan sebagai media pembelajaran prakarya dan kewirausahaan materi pokok sumber daya karya rekayasa elektronika praktis khususnya untuk kelas XII di SMA Negeri 4 Singaraja.

Adapun saran yang dapat disampaikan berdasarkan hasil penelitian ini adalah (1) Dengan adanya tingkat pencapaian dalam kualifikasi baik pada modul pembelajaran, diharapkan menjadi salah satu alternatif yang dapat digunakan untuk para guru, sehingga 
siswa akan lebih aktif dalam mengikuti pembelajaran, dan dapat belajar secara mandiri. (2) Kepada Guru Pengajar SMA Negeri 4 Singaraja yang terkait dengan pengembangan media pembelajaran agar dijadikan sebagai acuan untuk pengembangan media pembelajaran untuk materi pokok yang lainnya pada mata pelajaran prakarya dan kewirausahaan. (3) Bagi para peneliti yang berminat mengadakan penelitian pengembangan lebih lanjut tentang pengembangan bahan ajar berupa modul pembelajaran, hendaknya merancang desain modul pembelajaran yang lebih dapat memberikan kemenarikan bagi siswa untuk membantu dalam meningkatkan kualitas pembelajaran.

\section{Daftar Pustaka}

Arsyad, Azhar. 2006. Media Pembelajaran. Jakarta: PT Raja Grafindo Persada.

Asfiah, Nailin (dkk). 2013. Pengembangan Modul IPA Terpadu Kontekstual Pada Tema Bunyi. Semarang: Unnes Science Education Jurnal.

Irfan, A. 2014. Pengembangan Modul Pembelajaran pada Mata Kuliah Medan Elektromagnetik I di Jurusan Teknik Elektro Universitas Negeri Surabaya. Jurnal Pendidikan Teknik Elektro.

Muhafid, Ervian A. (dkk). 2013. Pengembangan Modul IPA Terpadu Berpendekatan Keterampilan Proses Pada Tema Bunyi di SMP Kelas VIII. Semarang: Unnes Science Education Journal, 2 (1).

Undang-Undang. 2003. Undang-Undang Republik Indonesia Nomor 20 Tahun 2003 Tentang Sistem Pendidikan Nasional. Jakarta: Sekretaris Negara Republik Indonesia.

Sugiyono. 2015. Metode Penelitian Pendidikan (Pendekatan Kuantitatif, Kualitatif, dan $R \& D)$. Bandung : Alfabeta.

Sugiyono. 2016. Statistika Untuk Penelitian. Bandung : Alfabeta

Syahrir, Susilawati. 2015. Pengembangan Modul Pembelajaran Matematika Siswa SMP. Mataram: Jurnal IImiah Mandala Education (JIME), 1 (2). 